\title{
Informal and Precarious Work: Insights from the Global South
}

\author{
Anita Hammer | 0000-0002-3637-5010 \\ Essex Business School, University of Essex, Colchester Campus, \\ Wivenhoe Park, Colchester $\mathrm{CO}_{4} 3 \mathrm{SQ}$, UK \\ anita.hammer@essex.ac.uk \\ Immanuel Ness \\ Political Science Department, Brooklyn College, City University of New York, \\ 2900 Bedford Avenue, Brooklyn, NY 11210, USA \\ iness@brooklyn.cuny.edu
}

\begin{abstract}
Informal and precarious work remains an enduring reality across the Global South and is growing fast in the North. A recognition that this form of work is the norm globally rather than the exception has ignited debates around analytical frames, activist strategies and development interventions. Engaging with Southern realities, as this special issue aims to do, helps contribute to a better understanding of this rising form of work globally while also providing insights into workers' resistance and development policy limitations. Through detailed case studies from across the Global South, this special issue argues that informal and precarious work needs to be studied as embedded in concrete, historical, political and social contexts. It highlights the heterogeneity and complexity of intersecting social and material relations that underpin informal and precarious work which has crucial implications for class dynamics and political agency of labour.
\end{abstract}

\section{Keywords}

agency - capital accumulation - class - labour - social relations - state - work 
The relentless growth of informal and precarious work globally poses analytical and political challenges for academic scholarship, activists and international development organisations. An enduring reality across the South, 'informal work' refers to work and employment which is low paid (often at subsistence level), insecure, unregulated and unprotected, i.e., without an employment contract or access to representation and social security. According to the International Labour Organization (ILO), ${ }^{1} 85.8 \%$ of total employment in Africa, $71.4 \%$ in Asia and the Pacific, $68.6 \%$ in the Arab States and $53.8 \%$ in the Americas is either informal (based in the informal economy) or informalised (situated within formal production but based on informal relations). Total informal employment for emerging and developing economies is at $69.6 \%$ and the extension of processes of precarisation across the whole Global North makes it $61.2 \%$ at world level. However, it is only recently that this category of re/emerging work has begun to gain attention in the North. ${ }^{2}$ A more widely used term in the North is 'precarious work', referring to work and employment which transfers social and economic risks from businesses and state institutions on to workers through common features like low pay, employment insecurity and insufficient social protection. ${ }^{3}$ Since it often takes the global North as its starting point precariousness signifies a shift away from welfare and labour market protections. ${ }^{4}$ Yet, precariousness has long characterised informal work and employment in the South. As Breman and van der Linden argue, labour informalisation is fast becoming a global norm and it is the 'West' now following the 'Rest' with regard to precarious labour relations. ${ }^{5}$ We contend a focus on everyday experiences and struggles of workers in the South, where informal and precarious work has long been a distinctive feature of working

1 International Labour Organization. Women and Men in the Informal Economy: A Statistical Picture. Third edition (Geneva: ILO, 2018). Available online at http://www.ilo.org/wcmsp5/ groups/public/—dgreports/dcomm/documents/publication/wcms_626831.pdf (accessed May 2020).

2 Hammer, N. and R. Plugor, 2019. "Disconnecting Labour? The Labour Process in the UK Fast Fashion Value Chain.” Work, Employment and Society 33(6) (2019), 913-928.

3 Kalleberg, A.L. "Precarious work, insecure workers: Employment relations in transition." American Sociological Review 74(1) (2009), 1-22.

4 Standing, G. The Precariat: The New Dangerous Class (London: Bloomsbury, 2011); Kalleberg, A.L. and K. Hewison. "Precarious Work and the Challenge for Asia." American Behavioral Scientist, 57(3) (2013), 271-288.

5 Breman, J. and M. van der Linden. "Informalizing the Economy: The Return of the Social Question at a Global Level." Development and Change 45 (2014), 920-940. 
lives with extraordinarily creative responses by workers to the challenges facing them, contributes to a better understanding of this rising form of work globally.

A focus on Southern realities of informal and precarious work reveals its embeddedness in concrete, historical, political and social contexts. It exposes analytical complexities and concrete variations that stem from intricate and intersecting production and social relations, with crucial implications for accumulation and class dynamics of informal and precarious labour. Extremely heterogeneous in its composition and characteristics, informal work includes a broad range of production and employment relations - from informal employment as wage, casual or day labour, to unpaid family labour, to informal outwork to dependent self-employment to petty commodity production among others. ${ }^{6}$ Underlying this heterogeneity are social relations of caste, community, gender, ethnicity and religion. ${ }^{7}$ Production relations intersect and combine with these social differences and divisions. From this heterogenous landscape, capital selectively and differentially incorporates workers with some contributing to accumulation while others are pauperised, or a combination of both. ${ }^{8}$ The state holds a key role in constructing informal work, not only through defining the scope of regulations but also by shaping the power relations between capital and labour. ${ }^{9}$

The study of informal and precarious work across the Global South unveils that exploitation can take many distinct forms. ${ }^{10}$ One of the ways scholarship on the South addresses the fragmentation of labour while underlining its shared position as members of the exploited class and maintaining focus

6 Chen, M.A. Rethinking the Informal Economy: Linkages with the Formal Economy and the Formal Regulatory Environment. Working Paper No. 46 (New York, NY: United Nations, 2007); Hammer, A. "Comparative Capitalism and Emerging Economies: Formal-Informal Economy Interlockages and implications for institutional analysis." Review of International Political Economy 26(2) (2019), 337-36o.

7 Harriss-White, B. and N. Gooptu. Mapping India's World of Unorganized Labour. In The Socialist Register 2001, eds. L. Panitch and C. Leys (London: Merlin Press, 2001), 89-118.

8 Sanyal, K. Rethinking capitalist development: Primitive accumulation, governmentality and post-colonial capitalism (New Delhi: Routledge, 2007).

9 Agarwala, R. Informal Labor, Formal Politics, and Dignified Discontent in India (Cambridge: Cambridge University Press, 2013); Harriss-White, B. "Globalisation, the financial crisis and petty production in India's socially regulated informal economy." Global Labour Journal 1(1) (2010), 152-177.

10 Banaji, J. Theory and History: Essays on Modes of Production and Exploitation (Leiden: Brill, 2011); Lerche, J. From 'Rural Labour' to 'Classes of Labour': Class Fragmentation, Caste and Class Struggle at the Bottom of the Indian Labour Hierarchy. In The Comparative Political Economy of Development. Africa and South Asia: eds. B. Harriss-White and J. Heyer (London: Routledge, 2010), 66-87. 
on the core antagonism between capital and labour is through the concept of 'classes of labour.'11 Classes of labour include the growing numbers who depend (directly and indirectly) on the sale of their labour power for their daily reproduction through insecure and oppressive wage employment, often combined with a range of precarious farming and informal activity, across different sites of the social division of labour and along intersecting lines of inequality such as class, gender, caste, religion and ethnicity. What does this mean for labour's agency and collective action, and political outcomes for informal and precarious workers who labour under the same capitalist relations as formal workers? Our approach questions suggestions examining unregulated work in both the Global North and South through the prism of insecurities or precarity, ${ }^{12}$ or the extent to which informal and precarious workers in the North and South present a class with a common interest. ${ }^{13}$ As argued by Breman, and illustrated in the contributions in this issue, there are different histories of work and inequalities in power and wealth between workers in the North and South, ${ }^{14}$ and it is important to acknowledge different needs as well as unorthodox solutions and radical alternatives brought about by labour struggles in the South. ${ }^{15}$

The persistence of informal and precarious work makes it central to development interventions, for example the United Nations' (UN) and ILO's focus on 'Decent Work', most recently epitomised in the UN 's Sustainable Development Goal 8 (sDg 8) on 'Decent Work and Economic Growth'. Decent work is crucial to the vast majority of workers who labour under insecure and precarious conditions with limited voice or social protection. While the goal is ambitious, universal and collective, a recent ILO report suggests progress on SDG 8 is slowing down and most countries have a long way to go towards achieving inclusive and decent work for all. ${ }^{16}$ It contends that failure to make headway on SDG 8 would also impede progress towards other SDG s, such as eradicating poverty, reducing inequalities, promoting peace, and achieving gender equality. We feel

11 Bernstein, H. 2007. Capital and labour from centre to margins, In Keynote address at the conference 'Living on the Margins', Stellenbosch University, 26-28 March, Cape Town, South Africa.

12 Beck, U. The brave new world of work. (Cambridge, MA: Polity Press, 2014).

13 Standing, 2011; Wright, E.O. "Is the Precariat a Class?" Global Labour Journal 7(2) (2016), 123-135.

14 Breman, J. "A bogus concept?" New Left Review 84 (November-December) (2013) 79-97.

15 Munck, R. "The Precariat: A view from the South." Third World Quarterly 34(5) (2013), 747-762; Scully, B. Precarity North and South: A Southern Critique of Guy Standing. Global Labour Journal 7(2) (2016), 16o-173; Ness, I. Southern Insurgency: The Coming of the Global Working Class (London: Pluto Press, 2016).

16 International Labour Organisation. Time to Act for SDG 8: Integrating Decent Work, Sustained Growth and Environmental Integrity (Geneva: ILO, 2019). 
it is a critical moment to focus on informal and precarious work to help analyse the failure towards achieving decent work. The purpose is not to unpick the decent work agenda, rather our argument is that the agenda and similar interventions fail because of insufficient attention paid to the heterogeneity and complexity of intersecting social and material relations that underpin informal and precarious work and its role in capital accumulation. Current attempts to regulate 'decent work' derive from abstract presumptions of a standard employment relationship and involve a generalizable regulatory fix to protect workers; missing the longer embedded histories of how precarious and informal labour relations are created and maintained. It relies on state's intervention to achieve decent work but does not account for the state's role in instituting or enabling informality and precarity as contributions in this special issue show.

Through our contributions, we capture and convey the heterogeneity and complexity that underlays informal and precarious work, identify key dimensions essential to any analysis of informal and precarious work and, thereby, to address the challenges it poses to development paradigms and class struggle. The contributions, with their varying approaches and focus, examine the critical role of informal and precarious work to accumulation and emphasise conflict between capital and labour as crucial to understanding differentiation of work and labour across the Global South. The asymmetric balance of power between capital and labour and the role of the state in instituting informal and precarious work and labour regimes are critical forces shaping accumulation. Capital actively reshapes the composition of the workforce to restrict the bargaining power of labour and reduce the value of labour power through mobilising social differences and divisions. Nevertheless, the same also creates opportunities for mobilisation and solidarity among formal and informal and precarious workers, resulting in resistance which is often more inclusive and broader spatially. These aspects are examined along the following dimensions: - $\quad$ Situated, diverse and intersecting relations of informal and precarious work

- The role of the state in instituting and/or enabling informal and precarious work

- Informal and precarious work, class consciousness and political action Engaging with Southern realities, as this special issue aims to do, would not only contribute to a better understanding of this rising form of work in the Global North, it will also provide insights into the policy failures in achieving decent work globally. This special issue is a joint effort by a collective of women academics, a number of them early career academics, who work on informal and precarious work in different contexts across the Global South; 
an effort supported by the editor Immanuel Ness. The articles were first presented at the special stream on 'Work and employment in the Global South', International Labour Process Conference, Vienna 2019. They draw upon different disciplines and perspectives, such as anthropology, economics, history, law, sociology and political economy. Analytical frameworks include feminist approaches, global value chains, labour process and institutional analyses. The contributions present workers' and unions' voices, while also engaging with state actors, national/local institutions and international frameworks.

Situated, Diverse and Intersecting Relations of Informal and Precarious Work

Informal and precarious work is based on diverse, complex and intersecting forms of production and social relations. There are multiple dimensions of precarity beyond the formal employment status and associated social rights: the autonomy over the labour process, ownership of the means of production, control over the valorisation process. Informal work includes a broad range of production and employment relations, exists in both formal and informal enterprises, and could be for survival or accumulation or a combination of both. Each of these production relations denotes different ways of organising production, different labour processes as well as forms of reproduction alongside different ways in which they may interlock (or not) with the formal economy. ${ }^{17}$ Different forms of production relations are characterised by distinct modalities of extracting value and are not isolated; on the contrary, they often substitute other forms, often key to re-arranging the spatial organisation of production networks. ${ }^{18}$ For example, in the auto sector, it is not uncommon for informal wage labour, apprentices and contract workers to work alongside full-time production workers to do the same job on the same shop floor, and for supply chains to run deep into the informal sector. ${ }^{19}$

The multiple production relations are intersected by relations of caste, community, gender, ethnicity and religion. The fragmentation of core workforces

17 Hammer, A. and A. Fishwick, eds. Introduction: Labour Process Analysis and Work in the Global South - A Dialogue, In The Political Economy of Work in the Global South: Reflections on Labour Process Theory (London: Red Globe Press, 2020), 1-19; Barnes, T. "Marxism and informal labour." Journal of Australian Political Economy 70 (2012), 144-166.

18 Barnes, T. Making Cars in the New India. Industry, Precarity and Informality (Cambridge: Cambridge University Press, 2018).

19 Ibid; Hammer, A. “Trade Unions in a Constrained Environment: Workers' Voices from a New Industrial Zone in India." Industrial Relations Journal 41(2) (2010), 168-184. 
emphasises differences in groups of workers along different social relations that constitute the basis for allocating workers to jobs and different disciplinary regimes. For example, a majority of poor, women, and marginalised caste and communities labour in the lower rungs of the informal economy i.e., as casual labour, homeworkers and as unpaid family labour in own-account firms. ${ }^{20}$ Therefore, it is crucial to distinguish between independent self-employment and dependent self-employment, the latter based on the authority relations of an employment relationship. Class dynamics underpinning informal and precarious work become pertinent in the context of different production relations across the Global South. The contributions in this issue analyse the wide range of production relations that characterise informal and precarious work and how these production relations are embedded in wider social relations.

The heterogeneity and intersections underpinning informal employment are brought out in sharp detail in Ilona Steiler's essay on informal workers in Tanzania. Steiler examines informal work in street trade and domestic work through the prism of intersectionality. Countering the mainstream argument that informality is a matter of legal coverage, Steiler argues regulation reflects and interacts with specific constellations of the categories of ethnicity/race, gender, age and marital status, education and skill level as well as of class. She convincingly argues informality of work results from the complex interplay of these categories with law, their historical development in Tanzania, the spatial organization of work and workers' visibility, and struggles over social status and power relations based on class. Steiler suggests this complexity and heterogeneity poses many challenges to the decent work agenda and recognizing these dynamics offers a better understanding to address decent work deficits.

The multiple dimensions of precarity that underpin informal work are keenly highlighted by Tulika Tripathi and Nripendra Mishra in their assessment of non-agricultural home-based own account enterprises in India. Countering the 'entrepreneurialism' myth that shift to self-employment signifies, they detail the 'hidden dependency' of self-employment, its gendered and caste and community-based nature, which is created through an intricate mechanism of subcontracting in global production networks. The self-employed are locked into unequal exchange relations with large firms or merchants and depend on intermediaries for equipment and production inputs. The dependency is compounded through payment by piece rates which underlie work intensification

20 Harriss-White and Gooptu, 2001; De Neve, G. The Everyday Politics of Labour: Working lives in India's Informal Economy (New Delhi: Social Science Press, 2005). 
and a reliance on self-exploitation and unpaid family labour. Despite the fact that there are multiple layers between the 'self-employed' and capital, extreme exploitation is involved, with capital paying these workers below the value needed to reproduce their labour power and taking advantage of their precarious position. Though not labelled as wage labour, the self-employed are precarious, informal workers prone to very similar exploitative processes as formal wage workers, or worse.

Questioning the 'Northern' focus of the precarity literature Bridget Kenny persuasively argues for a situated and historical analysis of the processes by which 'flexible' working time patterns came into being in the global retail labour process. In a historical piece based on extensive archival research, Kenny traces debates and struggles over store trading times (which determined working time) from the 196os to the 1980s in Johannesburg, and explores the connection of working time debates to the precarisation of retail labour in South Africa. She details how the struggles around working and trading hours took up gendered and racialized discourses as the labour market shifted over these decades and into the present.

The significance of informal work to capital accumulation is demonstrated by Danisha Kazi through her examinations of the critical role of informal wage labour and capital labour struggles in the automotive and auto component sector in India. Firms actively reshape the composition of the workforce to restrict the bargaining power of labour and reduce the value of labour power. This includes a growing preference for non-unionised rural and semi-rural workers and female workers. The asymmetric balance of power between capital and labour and the state's role in institutionalising a flexible labour regime are critical forces shaping capital accumulation, with implications for the structure and differentiation of the workforce. In a similar vein, Anna Salmivaara adopts a GVC perspective to examine how processes of in-fact informalization are produced through a systematic use of short-term contracts and subcontracting in Cambodia's garment industry in a hidden yet effective manner. Through a nuanced analysis, Salmivaara highlights the significant role of the state and workers in top-down and bottom-up processes of in-fact informalization, which prevent women workers from collectively claiming their legal entitlements. These processes assist the government's strategy of indirect rule aimed at ensuring political power, and are strengthened by the workers' insecure lives and gendered needs discouraging unionization; thereby, deepening informalization.

What do these class dynamics underpinning informal and precarious work and the fragmentation of labour mean for workers' resistance and political action? This is examined in the following sections. 


\section{The Role of the State in Instituting and/or Enabling Informal and Precarious Work}

Moving from class dynamics to class identities and struggle requires an understanding of the role of the state in securing the economic and social power of capital through its political and ideological rule, universally but not exclusively. The state plays a key role in the constitution of capitalist social relations: by shaping the conditions of work through regulation and repression, in mediating capital and labour relations, in shaping conditions for the reproduction of labour power through welfare mechanisms. ${ }^{21}$ As Poulantzas argues state institutions and apparatuses 'do not possess a power of their own distinct from class power. ${ }^{22}$ This understanding is contrary to the ILO approach which is closer to social democratic Keynesian ideology and Polanyi's ideas, i.e., assuming that labour per se is not exploited and the relentless accumulation drive of capital can be tamed by the state. ${ }^{23}$ As contributions to this special issue show, the state intervention (or lack of it) through policies, regulation and social security provisioning among others impact on how informality is created and instituted, how informalisation and precarisation proceeds, and the contradictory outcomes for labour.

Conceptualising informality in a historical context, Amal Shahid draws attention to labour informality as a direct product of state intervention under the famine-relief employment system in 19th century India. The colonial state co-constructed informality and precarity during famines through its famine policy and use of vulnerable famine-stricken labour. The famine policy, with its underlying premise of being a benevolent relief scheme, allowed for regulation of labour; however, resulting in labour informality. The state regulated 'famine labour' through famine codes, which codified employment conditions and employer-labour relations. Therefore, famine relief works were heavily regulated by the state but characterised by informality, that is, seasonal work, labour intensive work with low wage payments, and inconsistency in work to

21 Pearson, R. Gender, globalization and the reproduction of labour: Bringing the state back in. In New frontiers in feminist political economy, eds. S.M. Rai and G. Waylen (London: Routledge, 2014), 19-42; Chang, D.-O. Labour and the Developmental State: A critique of the Developmental State theory of labour, In Beyond the Developmental State: Industrial Policy in the Twenty-First Century, eds. B. Fine, J. Saraswati and D. Tavasci (London: Pluto, 2013), 85-103; Jessop, B. State Theory: Putting the Capitalist State in Its Place (University Park, PA: Penn State Press, 1990).

22 Poulantzas, N. 1978. State, Power, Socialism (London: Verso) 115.

23 For a critical assessment see Lerche, J. Labour Regulations and Labour Standards in India: Decent Work? Global Labour Journal 3(1) (2012), 16-39. 
allow cost reduction for relief. In the contemporary Indian context, Kazi scrutinizes how the state government actively reshapes capital and labour relations to serve its own class interests. Through her examination of informalisation of labour in the automotive sector, Kazi reveals how the state has institutionalised labour flexibility by pursuing industrial policies aimed at competitively seeking out large-scale investments which demand labour flexibility, and actively promotes low wage and non-unionised labour. Displaying a sort of race to the bottom in regulations, the state intervenes in industrial disputes to limit strikes and expands Export Processing Zones (EPZ s) where labour laws do not apply, and tacitly supports capital's strategies to undermine union rights.

The important role of the state in enabling the processes of informalization and weakening the power of unions in Cambodia is detailed by Salmivaara. The essay highlights the difference between the official commitments of the state to the labour rights, and the lived reality of the women garment workers. The ongoing in fact-informalization in the garment sector suits the interests of the Cambodian government by weakening freedom of association without explicit abandoning of commitments to international labour and human rights. Rather than interpreting Cambodian government's policy as mere pro-employer strategy, Salmivaara argues for seeing it as a form of indirect rule aimed at securing political control and regime survival without losing the legitimacy of adherence to national and international law.

That the state intervention can result in contradictory outcomes is the focus of Lorena Poblete's and Christina Teipen and Fabian Mehl's case studies on decent work and social upgrading, respectively. Poblete discusses the process of transforming predominantly informal domestic work into "decent work" in Argentina. Through an assessment of attempts to expand the scope of legislation and its enforcement to formalise domestic workers, Poblete analyses how the notion of informality and the conceptualization of this particular labour relationship, driven by the ILO's decent work agenda, condition institutional responses. The state's efforts to fit domestic work into the standard employment relationship, seeing it as key to access labour and social protections, results in a focus on full-time domestic workers while a majority of precarious domestic workers, working a few hours per week for several employers, are only marginally included within the scope of the law. The selective inclusion or exclusion of domestic workers from regulation has implications for attaining decent work.

Teipen and Mehl examine social upgrading, a concept that draws on the Decent Work Agenda and refers to the improvement of the situation of workers and encompasses measurable standards as well as enabling rights, trends in four global value chains across developing and emerging economies. They 
assess potential strategies to achieve decent working conditions along supply chains and highlight variegated upgrading dynamics across different countries and industries. They argue that prospects for social upgrading within similar segments of a particular value chain considerably depend on the national context; underscoring the importance of the role of national institutions.

Despite the strong role of the state in instituting or enabling informal and precarious work, the rule of capital and state is not always coherent or effective in containing the social contradictions of capitalism - in order both to pursue profit and accumulation and to secure legitimacy. Work remains a contested terrain of the state's repressive measures, pressures to facilitate accumulation, and agency of labour. ${ }^{24}$ Conceptualising the state as a terrain of class struggle allows for a number of possibilities, for example of possible ruptures and openings through which labour can confront repressive and ideological apparatuses of the state and capital's strategies. This is discussed in the next section.

\section{$4 \quad$ Informal and Precarious Work, Class Consciousness and Political Action}

The contradictory dynamics of capitalist social relations also include unintended consequences. The multiple ways in which capital and state fragment labour, the heterogeneity and complexity of labour, and the great variation in circumstances and experiences of labour, mean the translation from class relations to class consciousness, resistance and political action is always contingent and unpredictable. ${ }^{25}$ These processes are not experienced evidently and exclusively as class exploitation and oppression but in terms of specific identities like 'urban/rural workers, industrial workers/agricultural labourers, urban craftsmen and women peasants, men/women, mental/manual labour, young/old, black/white, regional, national and ethnic differences, and so on.' ${ }^{26}$ Moreover, capital mobilises the social divisions in how they recruit labour, organize it in production, and in how they deal with resistance from classes of labour.

24 Edwards, R. Contested terrain: the transformation of the workplace in the Twentieth century (London: Heinemann Educational, 1979); Poulantzas, 1978.

25 Bernstein, H. Class Dynamics of Agrarian Change (Halifax, NS and Winnipeg, MB: Fernwood, 2010).

26 Gibbon, P. and M. Neocosmos, M. Some Problems in the Political Economy of 'African Socialism'. In Contradictions of Accumulation in Africa. Studies in Economy and State, eds. H. Bernstein and B.K. Campbell (Beverly Hills, CA: Sage, 1985), 190. 
The diverse power dynamics and struggles that underpin the heterogeneity informal and precarious work have consequences for the economic survival strategies as well as different workers' resources and strategies of resistance. ${ }^{27}$ They can open new terrains of struggles, new forms of expression and new demands. Often spatially and temporally specific, they can also provide opportunities for global solidarity and political action. ${ }^{28}$ Here, Wright's framework on the sources of workers' power is helpful to understand the variations in struggles and outcomes of informal and precarious workers. According to Wright, workers derive their collective power from their 'structural power', i.e., from their specific 'location... within the economic system. ${ }^{29}$ Structural power includes 'marketplace bargaining power', i.e. the power that workers command due to conditions in the labour market, and 'work-place bargaining power', i.e., the degree of power workers can exert in a specific industrial location for their key position in the production process. However, workers' structural power does not necessarily result in workers' collective action. The latter rests on their 'associational power'. This derives from the political organization of workers along trade union lines, or other institutional forms, and on the limitations imposed on these forms by regulation and by the historical context of employment relations. Thus, there is no straightforward correlation 'between workers' bargaining power and the actual use by workers of that power to struggle for better working and living conditions. ${ }^{30}$ This suggests a number of possibilities where some forms of work and workers have more potential to disrupt and resist than others. The contributions in this issue provide insights into some of these challenges and opportunities for labour.

The challenges informal and precarious work poses to class consciousness and political organisation under globalising capitalism is captured in Steiler's essay. The street vendors and domestic workers in Tanzania belong to a broad class of workers doing precarious work in the informal economy but differ in terms of their employment relations as well as their working, social and cultural capital. These differences result from complex intersections of multiple social categories. Labour organization has been minimal, not least due to their

27 Sanyal K. and R. Bhattacharyya R. "Beyond the Factory: Globalisation, Informalisation of Production and the New Locations of Labour." Economic and Political Weekly 44(22) (2009), $35^{-44 .}$

28 Ness, 2016; Atzeni, M. and Ness, I. (eds.) 2018. Global Perspectives on Workers' and Labour Organizations. (Singapore: Springer).

29 Wright E.O. "Working-class power, capitalist-class interests, and class compromise." American Journal of Sociology 105(4) (2000), 957-1002, p. 962.

30 Silver, B.J. Forces of Labor: Workers' Movements and Globalization since 1870 (Cambridge: Cambridge University Press, 2003), p. 15. 
being labelled as 'informal'. Yet, Steiler underscores that despite the social differentiation of workers, the outcome of their struggles is not predetermined but open to their strategies and choices for a better life. The workers are aware and make concrete suggestions for minor and major improvements to their working lives, suggesting possibilities for involvement of workers, strengthening association, representation and collective bargaining, and workers' participation in political decision-making.

The outlook appears less sanguine for Tripathi and Mishra's self-employed in India. Capital's incorporation of households, women and disadvantaged groups into global production networks under the guise of self-employment has deepened exploitation, lengthened the working day, reduced earnings and increased precarity for these workers. It has decentred production from the workplace, made the employer-employee relationship ambiguous, and weakened the position of self-employed workers. Pauperisation is rampant. Capital is no longer in an ostensibly direct antagonistic relationship with labour; there are multiple layers in between. Yet, the fact that self-employed precarious labour is not labelled as wage labour does not mean that it is free from the antagonistic relationship with capital and that the class division is blurred or disappears. Whether or not they are 'formally' employed, extreme exploitation is involved; thereby, also the possibility of resistance. As the authors suggest, self-organisation or state interventions may alter power dynamics in favour of the self-employed.

The complexity of workers' experiences and choices in determining their strategies are underscored by Salmivaara. In Cambodia, many workers prefer conditions that in-fact informalize their work. Rather than a mere submission to short-term needs, or false consciousness, workers make realistic and pragmatic choices that are shaped by gendered responsibilities and long-term considerations determined by a context of historical insecurity, in which relations with authorities and foreign factory owners do not offer reasons for trust. The combination of insecure work and the gendered insecurity of life prevents workers from joining independent unions. The consequences are significant and extend beyond the workplace. At the factory level, the weakness of independent unions implies the inability to represent workers' interests in cases of labour rights violations. At societal level, it leads to lack of political representation. In-fact informalization effectively undoes freedom of association and prevents mobilization.

The historical role and trajectory of trade unions around store trading hours as a measure of working hours in the retail sector is charted by Kenny. She details how the struggles around working and trading hours took up gendered and racialized discourses as the labour market shifted. The unions 
negotiated the extension of trading time through bargaining off the working time of women workers, first white then black women, and then (mostly black) casual workers. This bargain defines retail workers' particular conditions in the present and affected the union's bargaining strategies into the post-apartheid period, as it worked to defend and protect its core membership of fulltime employees against casual workforce in the 199os; thereby, deepening divisions of labour. The association of casual labour as extra-ordinary and thus more available to work unsocial shifts conditioned the union's inability to protect these workers, and by consequence affected its membership levels and longer-term collective power in retail workplaces.

A new geography of labour discontent emerges in Kazi's study of the Karnataka's automotive sector in India, which contrasts with the common perception of Karnataka as an investor friendly state with a docile labour force. The state's elitist model of growth has historically prevented class and social based movements from emerging to challenge the power of established and new corporate elites. Yet, the growing presence of large-scale firms, the state's institutionalising of a flexible labour regime to attract private capital and the increasing informalisation of the workforce has led to more frequent and intense workers' struggles. This reveals the locus of labour's structural power against capital is beginning to shift to include the issue of informal wage labour within the formal sector. While challenges remain, this has forged a degree of solidarity across informal and formal workers in the automotive sector.

In the final contribution, Teipen and Mehl argue social upgrading trajectories crucially depend on the level of associational and institutional power that trade unions can exercise in transformation processes vis-à-vis the state and business interests. In their examination of GVC s across the Global South, Brazil and South Africa follow limited social upgrading paths, while social downgrading tendencies prevail in countries with weak trade unions such as India, Bangladesh and Vietnam. China occupies an intermediate position, where wages are beginning to rise but without any independent or collective representation of workers' interests. The dependence of Chinese as well as Vietnamese trade unions on state government parties has so far prevented social upgrading successes in the areas of freedom of association or collective bargaining. The mobilization of structural power resources through wildcat strikes has so far only led to temporary gains, which cannot be considered as comprehensive social upgrading without the recognition of independent trade unions as negotiating partners.

To conclude, this special issue aims to provide insights, which are by no means comprehensive, into class dynamics that underlay informal and precarious work and the translation from class relations to class consciousness 
and political action by informal and precarious labour which is contingent and unpredictable. It emphasises the need to pay attention to contexts, to specific production and social relations, and to the different structural and political constraints and possibilities that informal and precarious workers face. Informal and precarious work, like all work, is a contested terrain characterised by extreme exploitation but also potential for resistance and transformation.

\section{Author biography}

Anita Hammer is a Senior Lecturer in Sociology of Work and Employment at Essex Business School, University of Essex, Colchester, UK. Her research focuses on informal and precarious labour, social reproduction, automation and future of work, and workers' collective organisations. Anita has recently co-edited the volume The Political Economy of Work in the Global South: Reflections on Labour Process Theory (London: Red Globe Press, 2020). Recent research has been published in Review of International and Political Economy, Work Employment and Society, International Journal of HRM, and Industrial Relations Journal. Anita serves on the editorial board of Work Employment and Society and Journal of Labor and Society.

Immanuel Ness is a Professor of Political Science at Brooklyn College, City University of New York, New York, NY, USA. His research and published scholarly work focus on political economy of comparative labor movements, workers social organization, Global South political economy, socialism and contemporary imperialism. He is editor of Journal of Labor and Society (Brill). Ness is Senior Research Associate, Department of Sociology, Centre for Sociological Research and Practice, University of Johannesburg. He has recently authored Southern Insurgency: The Coming of the Global Working Class (Lomdon: Pluto Press, 2016) and co-edited Global Perspectives on Workers' and Labour Organizations (Singapore Springer, 2018). 